Eurasscience Journals

Eurasian Journal of Forest Science (2017) 5(1): 13-28

\title{
WILDLIFE HABITAT SUITABILITY ANALYSIS AROUND MADIHAN FOREST, MIRZAPUR DISTRICT, UTTAR PRADESH, INDIA: A GEOSPATIAL APPROACH
}

\author{
Laxmi Goparajuㄹ, Firoz Ahmad ${ }^{1}$ and Debadityo Sinha ${ }^{1 *}$ \\ ${ }^{1}$ Vindhyan Ecology and Natural History Foundation, Mirzapur, Uttar Pradesh, India \\ Vindhya Bachao Secretariat, 36/30, Shivpuri Colony, Station Road, Mirzapur-231001, Uttar Pradesh, India. \\ *debadityo@vindhyabachao.org
}

\begin{abstract}
The tropical dry deciduous forests of Mirzapur district in Uttar Pradesh (state) in India are facing severe threat from agricultural expansion, increased urbanization, infrastructure development and unsustainable use of forest produce. As a result the forests are now fragmented and wildlife habitat is vanishing. Dwindling numbers of wild animal species has become a cause of concern. The present study has analyzed satellite remote sensing data of Landsat OLI (2013) in conjunction with GIS and support of GPS to identify suitable habitat for wild animals. Various thematic maps like land use/land cover, forest cover type, lakes, roads and slope data were prepared in support of the objective of the paper. The weighted overlay method was used for integration of the thematic layers for identification of potential habitat and corridors for wild life movement. Most suitable (2.54\%), moderately suitable $(12.0 \%)$ and least suitable $(16.20 \%)$ areas were delineated and represented in a map. Highly suitable habitat was found at Dadri and Kotwa forest. Moderately suitable habitat was found in Darhi Ram forests. Least suitable areas were found in the outer fringes of Kotwa, Dadri, Darhi Ram and Sarson forests. Such data is the pre requisite for wildlife conservation effort.
\end{abstract}

Keywords: Dry deciduous, geospatial, habitat suitability, Mirzapur, Uttar Pradesh, weighted overlay, wildlife.

\section{Özet}

Hindistan Uttar Pradesh eyaletinde bulunan Mirzapur bölgesindeki kurakçıl ormanlar tarım alanlarının genişletilmesi, şehir alanlarının büyümesi, inşaat alanlarının artması ve orman kaynaklarının aşırı kullanımı ile çok yüksek bir baskı alında kalmaktadır. Bunun sonucu olarak, orman alanlarında bölünmeler olmakta ve yaban hayatı yok olma tehlikesi ile karşı karşıya kalmaktadır. Yaban hayatı sayısının azalması önemli bir tehdit hâline gelmiştir. Bu çalışma ile, Lansat OLI (2013) uydusuna ait uzaktan algilama verileri GIS ortamında GPS yardımıla kullanılarak yaban hayatına uygun alanların tespit edilmesi için analizler yapılmışır. Çalışmanın verilerini sunarken açıklayıcı olması maksadıyla, arazi kullanımı/arazi örtüsü, orman örtüsü tipi, göller, yol, eğim verisi gibi konu özlü tabaka haritalar kullanılmıştır. Yaban hayatına uygun yaşam alanlarının ve geçit koridorlarının belirlenmesi için, konu özlü harita tabakalarının ağırlıklandırmalı bindirme yöntemi kullanılmıştır. En uygun (\%2.54), orta uygun (\%12.0) ve en az uygun (\%16.2) alanlar haritalar üzerinde gösterilmiştir. En uygun alanlar Dadri ve Kotwa ormanlarında, orta uygunluktaki alanlar Darhi Ram ormanlarında ve en az uygun alanlar Kotwa, Dadri, Darhi Ram ve Sarson ormanlarının dış çevrelerinde tespit edilmiştir. Bu verilerin, yaban hayatı alanlarının korunması için çok yararlı olacağı düşünülmektedir.

Anahtar kelimeler: ağırlıklandırmalı bindirme, kurak yapraklı, mekânsal, Mirzapur, Uttar Pradesh, Yaban hayatı, yaşama alanı uygunluğu. 


\section{INTRODUCTION}

Amongst the terrestrial ecosystems tropical forest are one of the most species diverse Mayers 1991, 1992) and are capable of generating natural resources to provide sustainable livelihood to the local communities (Kumar et al. 2006). Tropical forests are more susceptible to degradation, depletion and conversion to other land uses and thus highly threatened and least protected ecosystems of the world (De Fries et al.2005) and are disappearing at an alarming rate owing to over exploitation of forest produce and lack of protection (Murphy and Lugo 1986, Raghubanshi and Tripathi 2009). Deforestation and degradation of forest leads to depletion of biodiversity in three ways: habitat destruction, breaking up of intact or contiguous forests into small forest fragments and changes in physical and biological consequences at the edge and periphery of forest-non-forest boundary (Pimm et al. 1995, Prance 1982.)

The forests of Mirzapur have eight forest ranges namely, Madihan, Mirzapur, Chunar, Sukrit, Wyndham Fall, Patehra, Lalganj and Drammadganj. Chandraprabha and Kaimur wild life sanctuary are present on either side. They mark the advent of one of the oldest mountain ranges of India, the Vindhyan range (Akhtar et al. 2004). The forests are facing various degrees of anthropogenic disturbance and are in various stages of forest fragmentation and degradation. Land use and land cover of this region have witnessed drastic changes since (2010-2013) as reported by Goparaju and Sinha 2015. Lack of proper knowledge and database of wild life species in this area has limited the conservation efforts. The greatest challenge to preserve wildlife is to maintain biological integrity of the surrounding habitat mosaic and connectivity between the remnant core areas to maintain vital ecological connections by providing physical linkages between these areas (Mondol et al. 2010, Kamat 1986).

Traditional methods and ground based studies have been employed in studying wildlife habitat and corridor use (Bhat and Rawat 1995, Johnsingh and Joshua 1994, Mishra and Johnsingh 1996). They are time consuming and inefficient in hilly and inaccessible areas. Satellite remote sensing provides us data at regular intervals and of different spatial and spectral resolution when in Geographic
Information System (GIS) domain to achieve a particular target. In addition, Geographic Positioning System (GPS) provides accurate information about the location of landscape features. Analysis and integration of various data can enlighten us about suitable habitats and provide insights into management and conservation plans. Studies in wildlife using geospatial technology have been gaining importance since the past few decades in India and have emphasized its role in habitat evaluation, identification and management of wildlife corridors (Khanna et al. 2001, Kushwaha and Hazarika 2004, Nandy et al. 2007). Remotely sensed data helps in identifying changes in land use /land cover, habitat attributes, new locations for protected areas and current scenario of wildlife corridors (Kamat 1986, Panwar 1986) and to monitor ecological impacts changes within corridors and to provide capabilities to study and interpret wildlife habitat info on different time scales (Yadav et al. 2011, Areendran et al. 2011, Nandy et al. 2007).

\section{The Objectives}

The study analyzes the Kotwa, Patewar, Darhi Ram and Sarson forests which constitute the Madihan forest range of Mirzapur forest division. The two main objectives of this study are to identify

1. Potential habitats for wild animals found in and around Madihan forests in Mirzapur district, Uttar Pradesh, India.

2. Suitable corridors (reintegration of forest patches) for wildlife movement and conservation.

\section{The study area}

The study was carried out in Madihan forest range in Mirzapur district of Uttar Pradesh (state) of India which lies between $25^{\circ} 0^{\prime} 8.83^{\prime \prime} \mathrm{N}$ to $24^{\circ} 56^{\prime} 37.61^{\prime \prime} \mathrm{N}$ and $82^{\circ} 37^{\prime} 31.91 " \mathrm{E}$ to $82^{\circ} 45^{\prime} 59.10^{\prime \prime} \mathrm{E}$. The total study area analyzed is $156,466.26$ ha and the forest area is $31,380.03$ ha. The climate here is characterized by three distinct seasons, the summer season (March - June) is hot and dry when temperatures can reach as high as $48^{\circ} \mathrm{C}$; warm and humid rainy season (July-October) where rainfall varies from $90-100 \mathrm{~cm}$, cool dry winter (November - February) when temperatures can be as low as $6^{\circ} \mathrm{C}$ (Singh 2007). The soil varies from loamy sand to clay. Variation in colour of soil is observed from 
red to yellow (Das et al. 2007). The terrain is undulating with hillocks dominating. (Figure 1 location of the study area).

The forests of this region are best described as tropical dry deciduous forest (Champion and Seth 1968). Large areas are of 5A/C3 and 5B/C2 types of forests, i.e., Southern and Northern Tropical Dry Deciduous Forests respectively. The flora is dominated by tree species such as Shorea robusta, Boswellia serrata, Anogeissus latifolia, Terminalia arjuna, Lagerstroemia parviflora, Hardwickia binnata, Acacia catechu, Butea monosperma, Zizyphus glaberrima,
Diopsyros melanoxylon. Pterocarpus marsupium, Holorrbena antidysentrica, Emblica officinalis, Synzygium cumini, Tectona grandis, Madbuca longifolia.

Important wild fauna of this region constitutes animals like Sloth Bear, Leopard, Sambhar, Black Buck, Chinkara, Monkeys, Langurs Peafowl, Bengal Monitor; Mugger Crocodile Nilgai etc which have their habitat in these forests. Tree species like Diospyos melanoxylon, Zizyphus mauritina, Cassia fistula, Aegle marmelos, Buchnania lanzen and Zizyphus oenophila provide food and shelter to these animals.

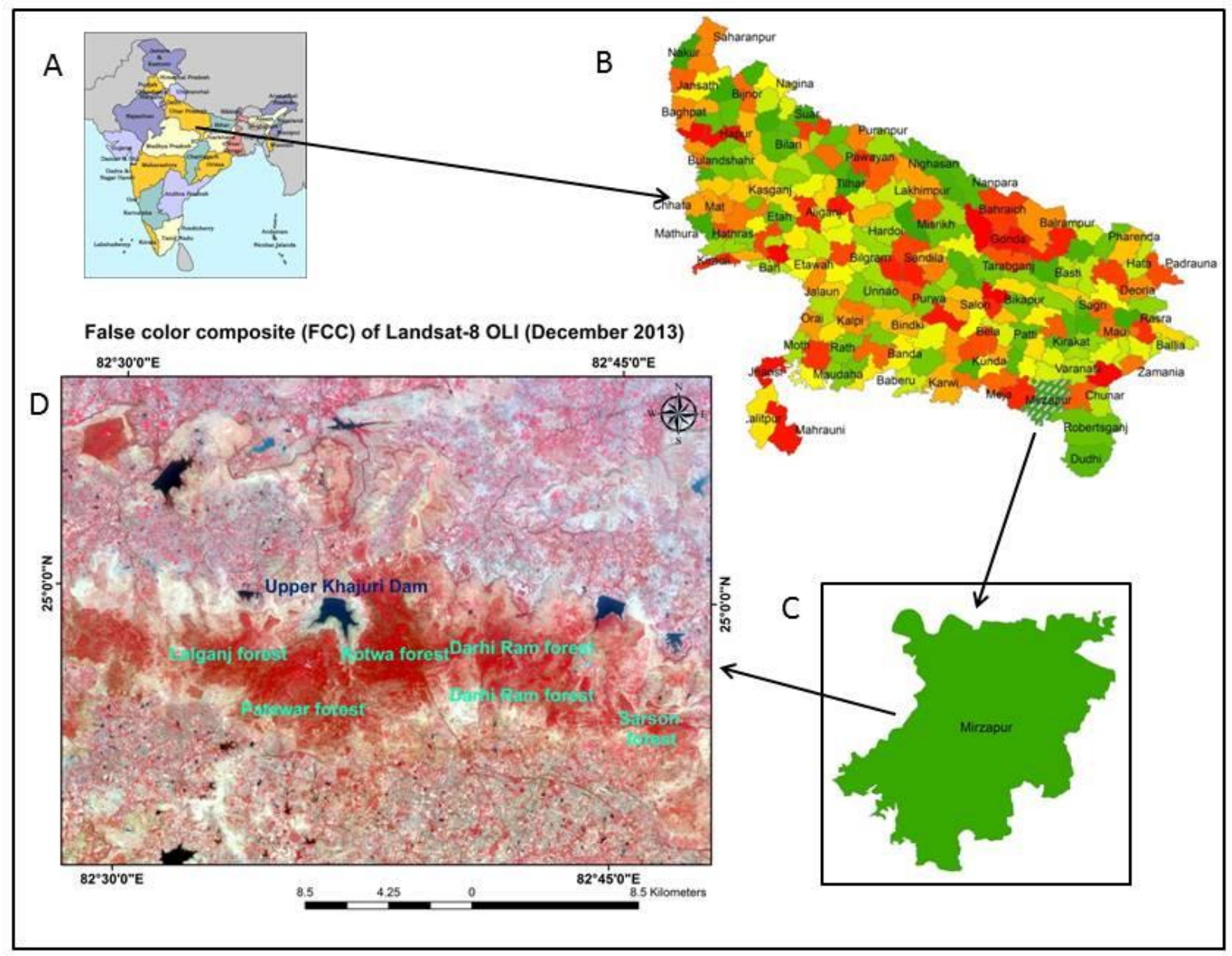

Figure 1: The location of the study area A) Country- India B) State- Uttar Pradesh C)District - Mirzapur and D) Madhihan forests and their surroundings. 


\section{MATERIAL AND METHODS}

\section{Image processing and classification}

The Landsat OLI (dated 25-11-2013) (Path/Row $142 / 43)$ data was selected. It was taken care to choose a cloud free data for the analysis. The data was downloaded from the portal of United States Geological Survey (USGS) as a geo-referenced and radiometrically corrected at the preliminary stage. There were eleven bands obtained (in TIFF format) which were layer stacked to produce a composite image and then converted into IMG (format) for further analysis. The projection details are as follows: Projection UTM, Zone 44; Spheroid, WGS 84; Datum, WGS 84. The spatial resolution of the data is $30 \mathrm{~m}$. The spectral bands used for the analysis are Band 5 (NIR - 0.85- $0.89 \mu \mathrm{m})$, Band 4 (RED- 0.63-0.68 $\mu \mathrm{m}$ ) and Band 3 (GREEN - 0.53$0.60 \mu \mathrm{m})$. Image processing software used is ERDAS imaging (version 9.0) and ARC GIS spatial analyst (version 10.0).

Thematic maps like land use/land cover and forest cover map were prepared after image processing techniques were applied for the above data. Other thematic layers like road, streams, etc., were downloaded from DIVA -GIS. Elevation data (DEM) was also downloaded from ASTER DEM.

\section{Field data collection}

GPS has been successfully used in wildlife studies because of its simplicity of use and ability to provide accurate locational information. It helps in overcoming issues related with traditional mapping techniques (Harris et al. 1990, Gooding et al. 1997). The forest department conducts census for the wildlife every two years using the traditional methods of survey. Inadequate information on the presence of wildlife species and their locations has hindered the protective measures to be taken. Besides, GPS locations will provide information to determine the home ranges of some big animals like Sloth Bear, their dens and preferences for various floras.

Utilizing Global Positioning System (GPS) during field survey, sighting location amidst forest patches were tracked and noted along patches of forests, grasslands and reservoirs. For tracking our route, we used an advanced android tablet of Samsung 2GT-P3110 version 7 model GT-P3110, which has in-built satellite GPS enabled system. The tablet was able to lock satellites within 30 seconds to 2 minutes and it gave us resolution of up to 5 meters during our field survey. A free Android app named 'AndroiTS GPS Test' was used to trace locations, record our track and marking areas where anything specific was observed. The location was further supplemented by GPS-enabled Camera Sony model no. HX400V which would record GPS coordinates of all photographs taken. During our field visit, great human disturbances were observed and forested areas appeared in patches. There were occasional sightings of Nilgai, Chinkara, Black buck and other small mammals like Jackal, Mongoose and reptiles like Bengal Monitor during our visit. Big mammals like Sloth bears could not be sighted but their presence could be understood from evidences (scats, scratch marks and soil dug out) interviews of local villager survivors of bear attacks and discussion with forest guards.

The saved co-ordinates were converted into KMZ file on Google Earth. Later converted into Shape file in ARC GIS (version 10.0) and used for analysis. Buffer of this GPS sighting (buffer of line) was generated. The weights assigned are given in table 1 .

Table 1: Weights assigned for GPS sighting buffer

\begin{tabular}{|l|c|}
\hline GPS sighting buffer & Assigned weight \\
\hline Buffer 0-500 meter & 9 \\
\hline Buffer 500-1000 meter & 7 \\
\hline Buffer 1000-1500 meter & 5 \\
\hline outside 1500 buffer & 2 \\
\hline
\end{tabular}




\section{Land use/Land cover classification}

To delineate various land use and land cover classes, visual interpretation technique in image processing was used. Various land form features were identified from false colour composite (FCC) using the photographic and geotechnical elements (Lillisend and Keifer 2004, Javed and Khan 2012). Five-six training sets were given for each class to capture the variation in the scene, based on field knowledge and visual interpretation. Later, the training sets were merged to form a single representative class. Further, Supervised classification using maximum likelihood algorithm was executed to delineate five major land use/land cover classes, Agriculture/Fallow/Settlement; Fallow/Urban/Settlement; Open fallow; Water; Dense forest and Open forest. The accuracy of the classified dataset was 88.67\% (Goparaju and Sinha 2015).The weights assigned are as follows in table 2:

Table 2: Weights assigned for land use/land cover class

\begin{tabular}{|l|c|}
\hline $\begin{array}{l}\text { Land use/ land cover } \\
\text { class }\end{array}$ & $\begin{array}{l}\text { Assigned } \\
\text { weight (Scale 1- } \\
\text { 9) }\end{array}$ \\
\hline & \\
\hline Agriculture/settlements & 2 \\
\hline Fallow/Urban/Agriculture & 2 \\
\hline Open fallow & 3 \\
\hline Open forest & 7 \\
\hline Dense forest & 9 \\
\hline
\end{tabular}

\subsection{Forest cover classification:}

A detailed classification is difficult to achieve where similarities are observed in canopy structure and spatial mixing is evident in dry deciduous species. Unsupervised classification (such as ISODATA and $\mathrm{K}$-means clustering) is capable of generating spectral groups where the statistical information obtained from remote sensing data plays a vital role. In this case human input is minimum and has the advantage of repetitions in the form of iterations (Pu 2009, Lu and Weng 2007 and Lang et al. 2008). It recognizes spectrally similar classes which at times would have been missed and grouped into other classes when other classification methods are used. In the present case, the forests are patchy in nature and occupy small areas, boundaries are not well defined among various cover classes. Therefore, in this study unsupervised classification was used to delineate the forest cover classes.

Forest cover classes were derived by masking out the forest area from false colour composite (FCC). An unsupervised classification executed exclusively on the forest area yielded ten forest cover classes spectrally. The accuracy of the classified dataset is $89.31 \%$. The classes are 1) Dense forest/Plantation, 2) Dense mixed forest 3) Open mixed forest 4) Shrubland 5) Degraded forest 6) Fragmented mixed forest 7) Open scrub 8) Scrubland 9) Grassland 10) Woodland. The weights assigned for each class are as follows in table 3:

Table 3: Weights assigned for Forest class

\begin{tabular}{|l|c|}
\hline Forest class & $\begin{array}{c}\text { Assigned weight } \\
\text { (Scale 1-9) }\end{array}$ \\
\hline $\begin{array}{l}\text { Dense } \\
\text { forest/plantation }\end{array}$ & 9 \\
$\begin{array}{l}\text { Dense mixed } \\
\text { forest }\end{array}$ & 8 \\
\hline open mixed forest & 7 \\
\hline Shrubland & 6 \\
\hline Degraded forest & 3 \\
\hline $\begin{array}{l}\text { Fragmented mixed } \\
\text { forest patches }\end{array}$ & 5 \\
\hline Scrubland & 3 \\
\hline Open scrub & 2 \\
\hline Grassland & 2 \\
\hline Woodland & 2 \\
\hline
\end{tabular}

\subsection{Other Thematic layers:}

The roads shape file was extracted as per the study area. Buffer was generated (using Euclidean distance in ARC GIS spatial analyst. The weights given for each buffer ring are given in table 4: 
Table 4: Weights assigned for road buffer

\begin{tabular}{|l|c|}
\hline ROAD buffer & Assigned weight \\
\hline Buffer $0-1 \mathrm{~km}$ & 2 \\
\hline Buffer $1-2 \mathrm{~km}$ & 3 \\
\hline Buffer $2-3 \mathrm{~km}$ & 4 \\
\hline $\begin{array}{l}\text { outside } 3 \mathrm{~km} \\
\text { buffer }\end{array}$ & 5 \\
\hline
\end{tabular}

Drainage layer was extracted from Digital Elevation Model (DEM) of the study area using ARC GIS Hydrology tool. Each order of drainage was assigned given a weight as follows in table 5:

Table 5: Weights assigned for drainage buffer

\begin{tabular}{|c|c|}
\hline $\begin{array}{c}\text { Drainage } \\
\text { buffer(100m) }\end{array}$ & $\begin{array}{l}\text { Assigned } \\
\text { weight }\end{array}$ \\
\hline First order & 5 \\
\hline Second order & 4 \\
\hline Third order & 3 \\
\hline Fourth order & 2 \\
\hline Fifth order & 2 \\
\hline outside buffer & 1 \\
\hline
\end{tabular}

Slope data was extracted from DEM in ARC GIS (Surface tool) for the study area and utilized in analysis. The weights given for each class is given in table 6:

Table 6: Weights assigned for slope class

\begin{tabular}{|l|c|c|}
\hline Slope class & $\begin{array}{l}\text { percent } \\
\text { slope }\end{array}$ & $\begin{array}{l}\text { Assigned } \\
\text { weight }\end{array}$ \\
\hline $\begin{array}{l}\text { water(nearly } \\
\text { level) }\end{array}$ & $0 \%$ & 1 \\
\hline Gentle & $0-5 \%$ & 2 \\
\hline Moderate & $5-10 \%$ & 5 \\
\hline Strong & $10-25 \%$ & 4 \\
\hline Steep & $25-35$ & 3 \\
\hline Very steep & $>35 \%$ & 2 \\
\hline
\end{tabular}

Lakes thematic layer was downloaded from DIVA GIS. A subset of this layer was extracted according to the study area. Weights given for each buffer class are given in table 7 .

Table 7: Weights assigned for lake buffer

\begin{tabular}{|l|c|}
\hline $\begin{array}{l}\text { LAKE } \\
\text { buffer }\end{array}$ & $\begin{array}{c}\text { Assigned } \\
\text { weight }\end{array}$ \\
\hline $\begin{array}{l}\text { Buffer 0-1.5 } \\
\mathrm{km}\end{array}$ & 5 \\
\hline $\begin{array}{l}\text { Buffer 1.5-3 } \\
\mathrm{km}\end{array}$ & 4 \\
\hline $\begin{array}{l}\text { Buffer3-4.5 } \\
\mathrm{km}\end{array}$ & 3 \\
\hline $\begin{array}{l}\text { Buffer4.5-6 } \\
\mathrm{km}\end{array}$ & 2 \\
\hline $\begin{array}{l}\text { outside 6 km } \\
\text { buffer }\end{array}$ & 1 \\
\hline
\end{tabular}

These thematic layers were added (along with their weights) in model maker in ERDAS Imagine to obtain a composite map of wildlife suitability (Figure 2- the flow chart). At the creation of Wildlife Suitability map stage, each thematic layer were directly integrated providing equal weight to each layer. The final map shows areas of high suitability, moderate suitability, low suitability and no suitability. Figure 3 - showing the various thematic layers used. 


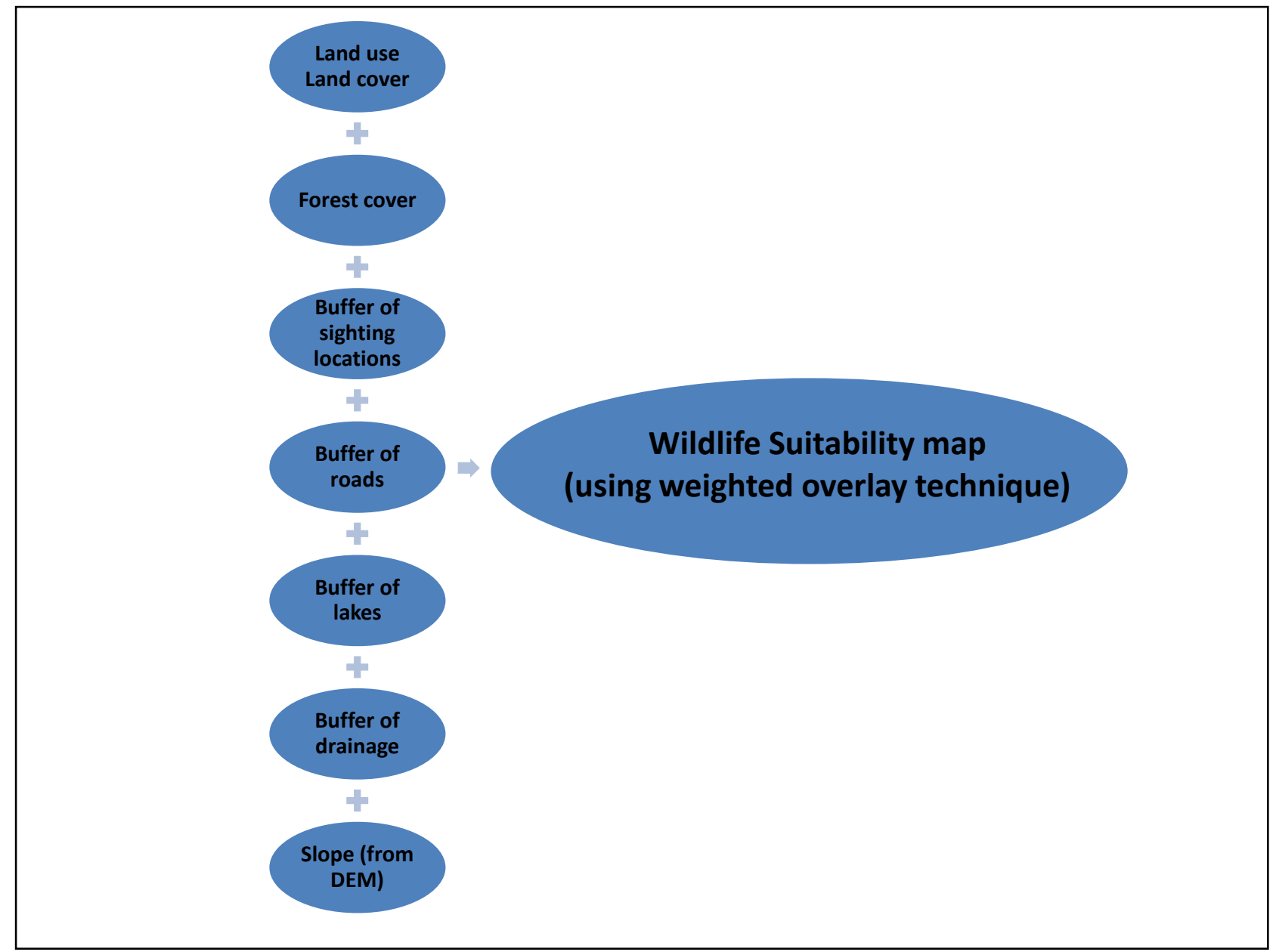

Figure 2. Flow chart explaining the methodology of the study 


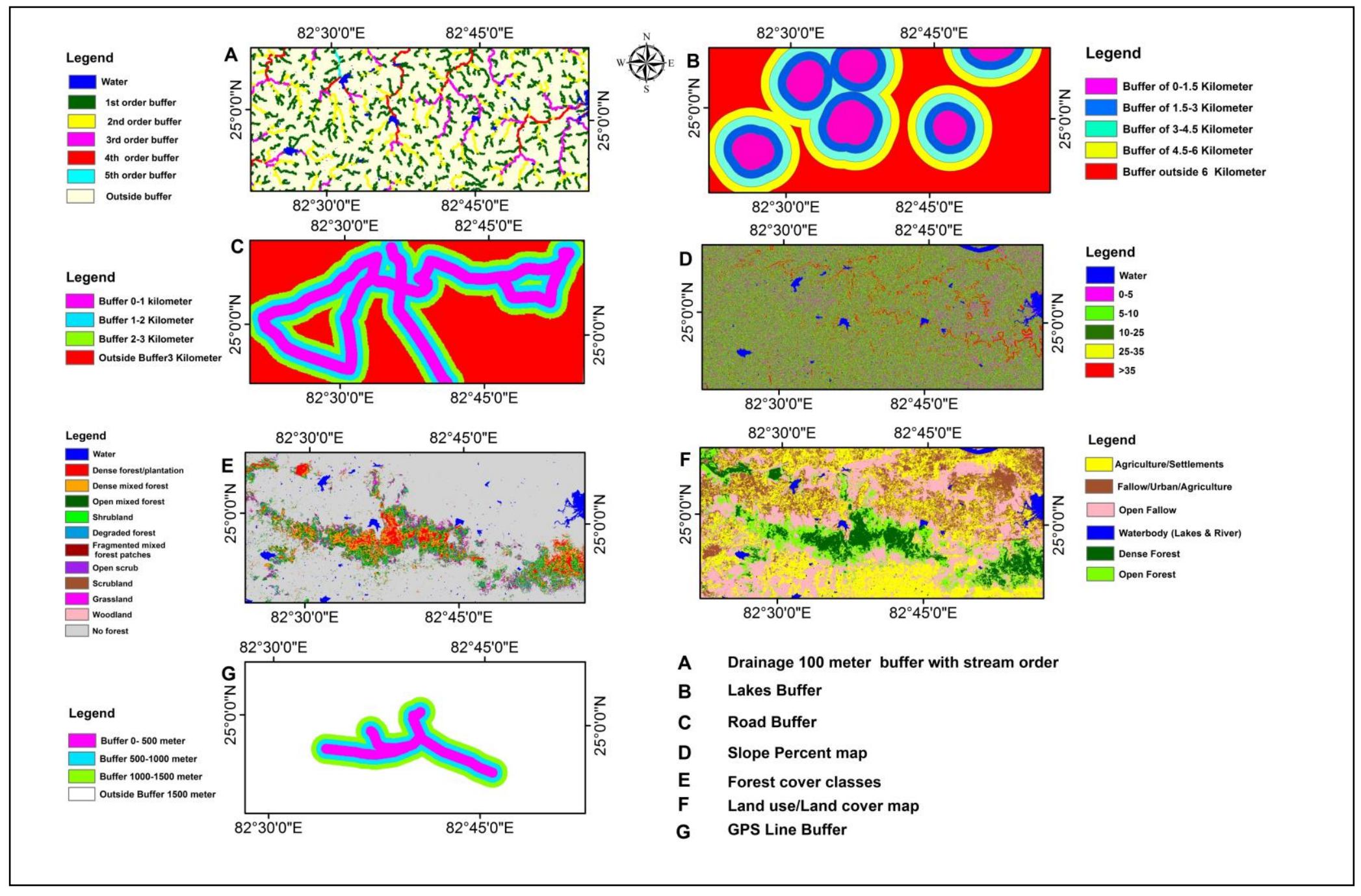

Figure 3: Various thematic layers used for analysis A) Buffer of Drainage B) Lakes buffer C) Road buffer D) Slope percent E) Forest cover classes F) Land use/Land cover G) GPS line buffer. 


\section{RESULTS AND DISCUSSION}

The results obtained are: highly suitable area was found to be $2.45 \%$ (of the total area analysed). Moderately suitable area constitutes an area of $12.0 \%$ (of the total area analysed). Least suitable area was found to be $16.2 \%$ (of the total area analysed).

Dadri /Kotwa forest: It is the densest of the ranges (figure 5). It is endowed with rich biodiversity and known for medicinal plants (Singh and Narain 2009). The terrain consists of short heighted hills with gentle slopes. The hill tops are comparatively less accessible and thus are good habitat for wildlife. They have been less explored due to inaccessible terrain and fear of wild animals as reported by the villagers. Highly suitable areas on the map have been found on the hill tops, thus this area needs to be safeguarded against further destruction. No developmental activity should be encouraged in this area.

Forests harboring near villages like Dadri Gariha and Dadri Khurd have reported areas having moderately suitable habitat for wildlife. Such areas should be protected from agricultural invasion or encroachment and infrastructural development which otherwise would destroy their homes. Agriculture encroachment should be discouraged, as it would give rise to human-wildlife conflict.

Darhi Ram forests: Moderately suitable areas were found in these forests which are highly disturbed due to increasing pressure of urbanization (figure 4). The outer fringes of these forests are highly fragmented and form the least suitable habitat for wildlife. Urbanization has increased settlements and agricultural plots. The forested region should be protected as they provide food and shelter to the wild animals, if destroyed then they will move towards the city side.

Kotwa-Patewar-Lalganj forests: At Kotwa, (figure 4) there is a plantation taken care by the forest officials occurring along with mixed forest. However, it is observed as highly suitable habitat for the wildlife. Forests at higher elevation in Patewar have reported to be highly suitable for wildlife. Lalganj forests are highly disturbed due to urbanization. It provides moderately suitable habitat for wild animals. The outer edges of these forests provide the least suitable areas for wild life existence. They should be protected such that the wildlife habitat is safeguarded against further deterioration. The fragmented forest patches should be connected such that they are protected against isolation. It will provide a corridor for wildlife movement. Good conservation practices can transform them into highly suitable areas.

Sarson forests: Adjoining the Darhi Ram forests, are the Sarson forest where good presence of Sloth bears have been noted. Hill tops are seen to be highly suitable areas, and surrounding forests provide moderately suitable habitat. A large proportion of forests observed as least suitable habitat are the outer margins of the forests. If protected properly, it can be converted as a moderately suitable habitat for wildlife movement (figure 6).

Not suitable area: It constitutes $67.08 \%$ of the total area analysed. Mostly agriculture, fallow areas were found to constitute this area.

Figure 7 and 8 show the presence of wildlife in the vicinity of the Madhihan forests where Chinkara and Nilgai have been spotted. Figure 9 and 10 show the present status of Madhihan forests.

\section{CONCLUSION}

The study has enlightened role of geospatial technology in identifying potential wildlife habitat. This is the first step towards any conservation programme. The use of coarse resolution satellite data like Landsat OLI data and various thematic layers available in public domain can be utilized by forest managers and conservationist. Geospatial technology provides the potential for accurate, time saving and cost effective methodology to solve wildlife conservation problems.

\section{Acknowledgement}

The authors are grateful to landsat.usgs.gov, for providing the Landsat satellite data used for analysis in the study and www.diva-gis.org for providing various GIS data. We also thank the World Wide Fund for Nature (WWF), India - for their financial support. We also appreciate the Vindhya Bachao members Shri Shiva Kumar 
Upadhayaya and Mukesh Kumar for their efforts in ground truth collection.

Wildlife suitability map of the Darhi Ram forest (Landsat 8 OLI-2013 analysis)

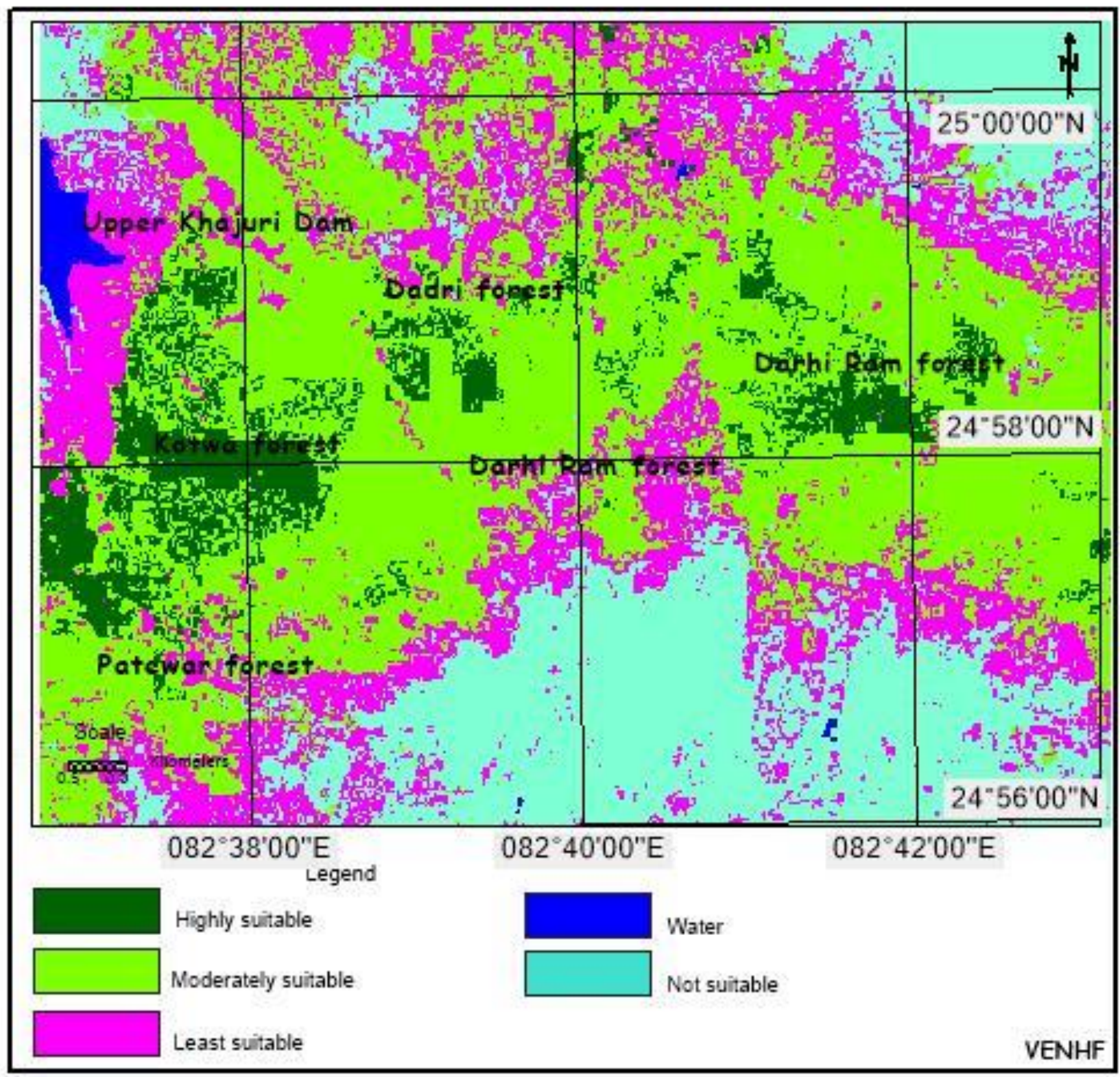

Figure 4 - Wildlife Suitability map 
Wildlife suitability map of the Kotwa block and adjoining forests (Landsat 8 OLI-2013 analysis)

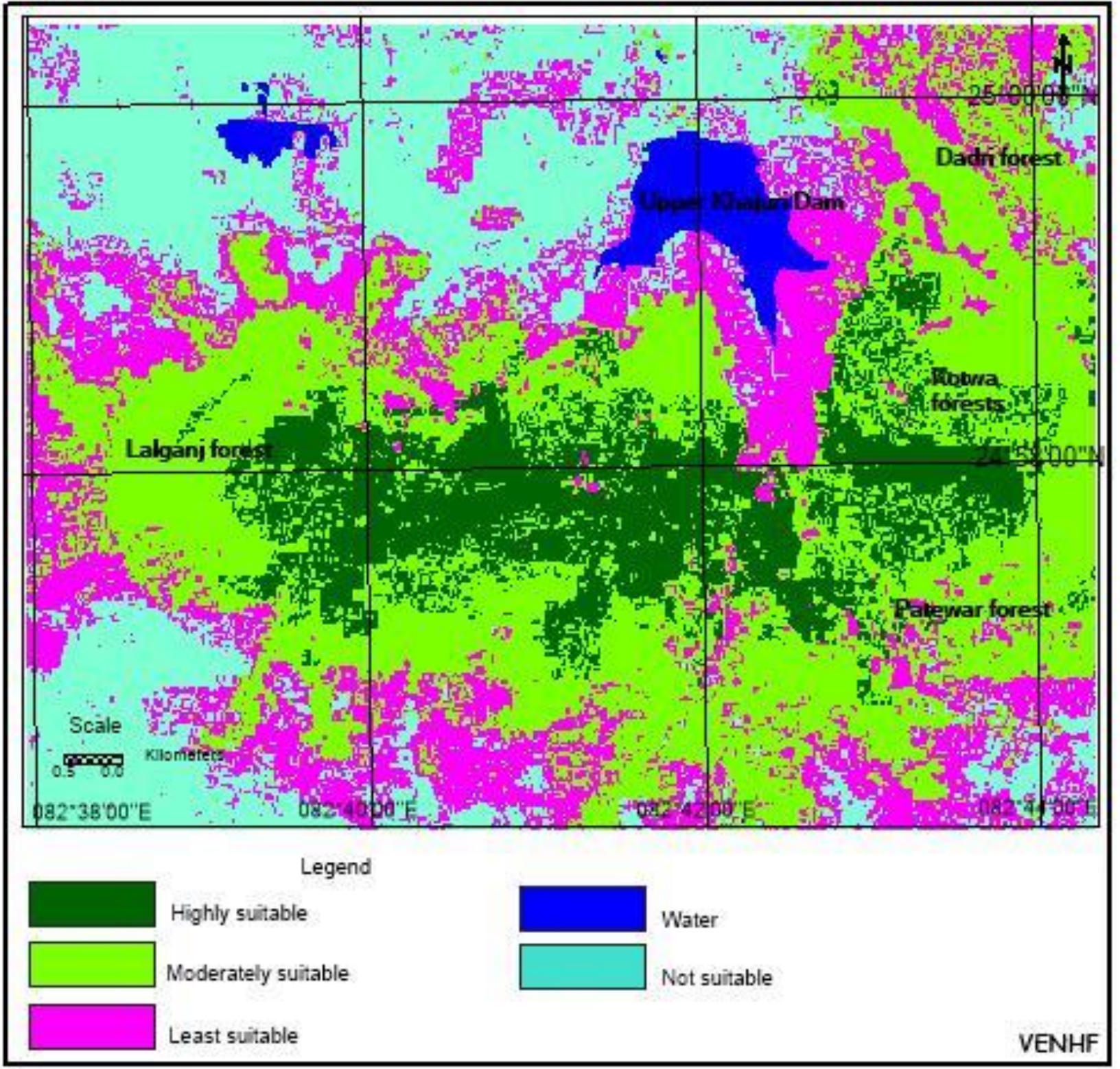

Figure 5 - Wildlife suitability map 
Wildife suitability map of the Sarson and adjoining forest (Landsat 8 OLI-2013 analysis)

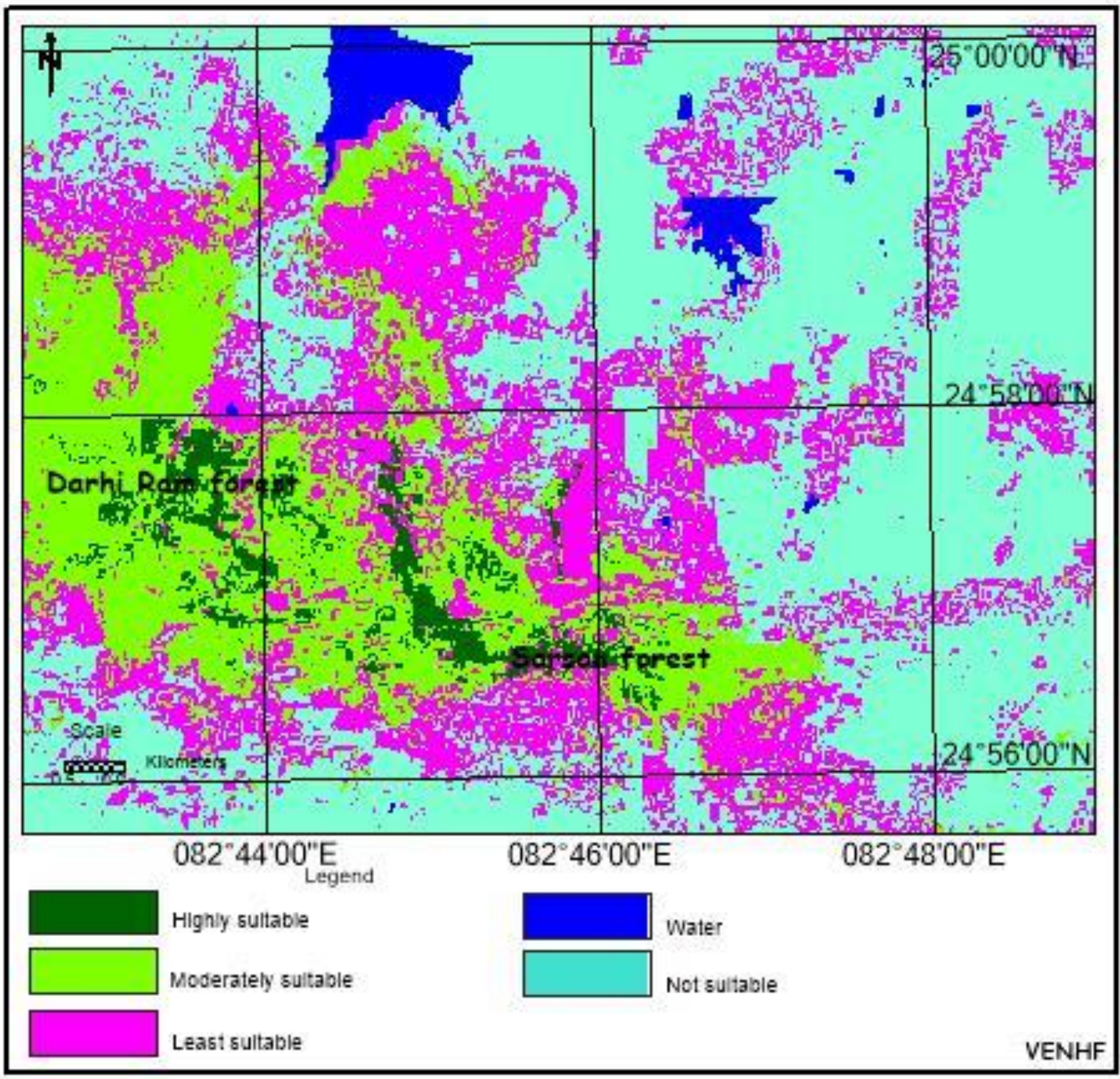

Figure 6 - Wildlife suitability map 


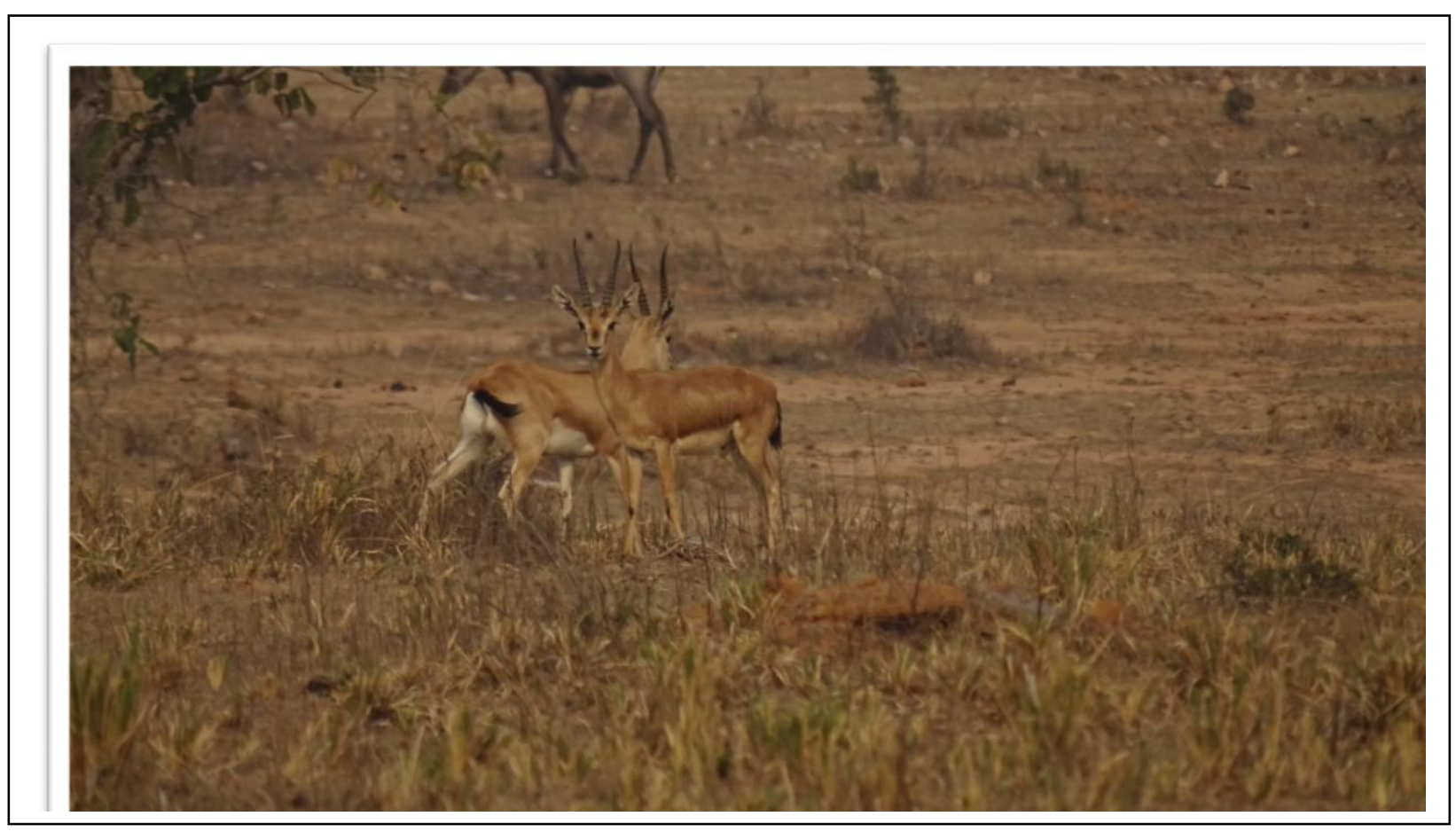

Figure 7 - Chinkara spotted in Madihan forests

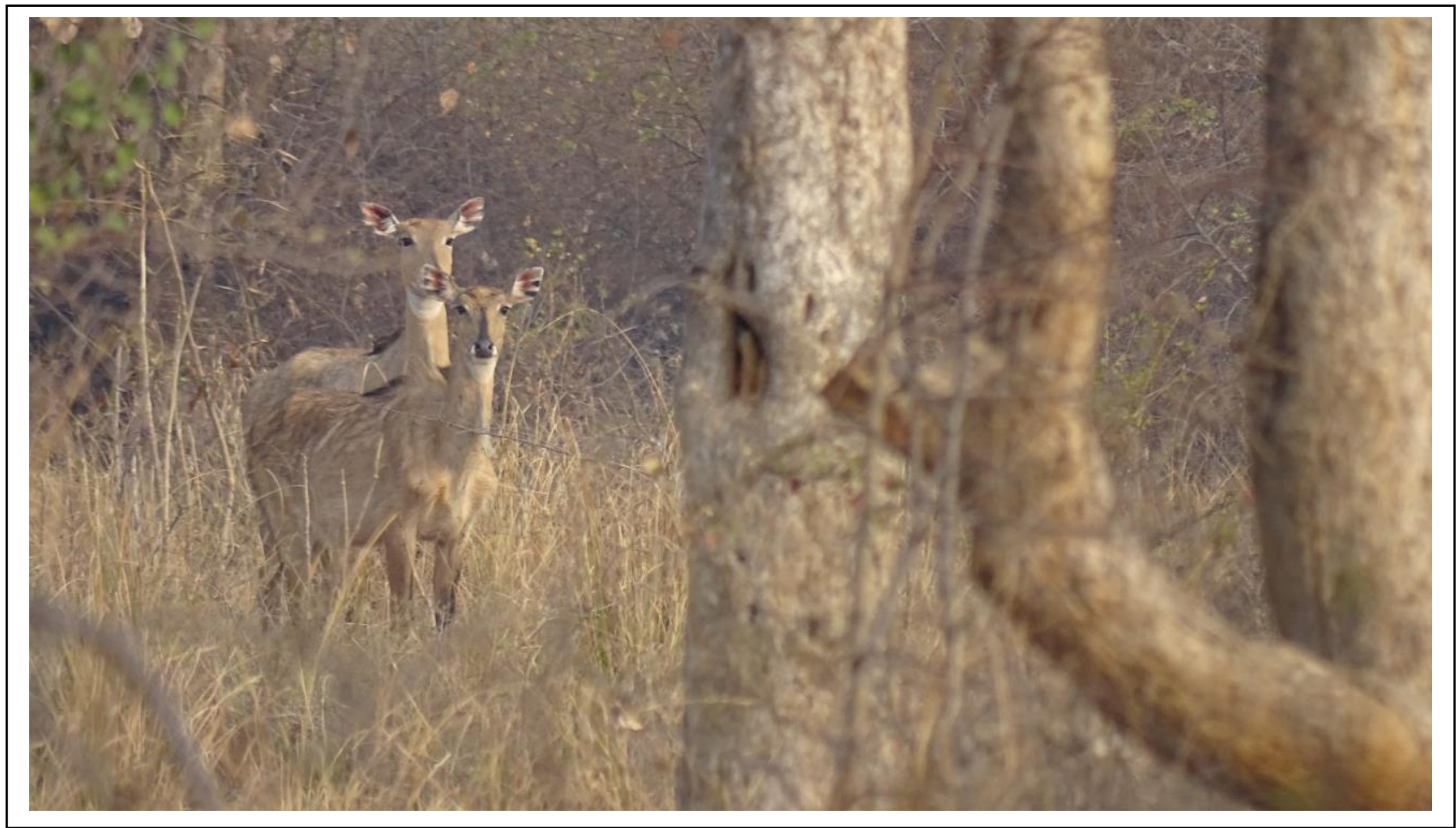

Figure 8 - Nilgai seen in Madhihan forests 


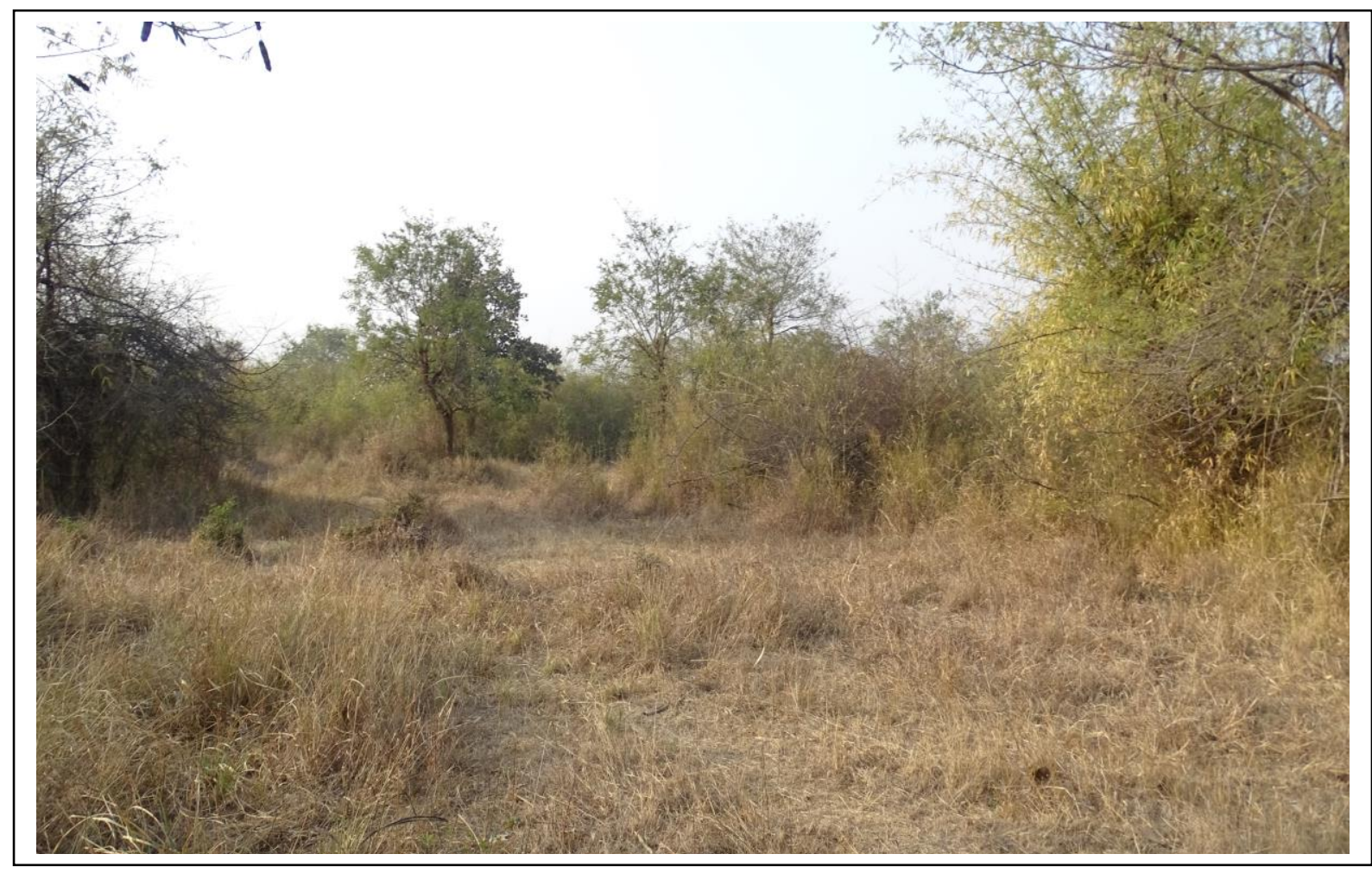

Figure 9 - Madihan forests

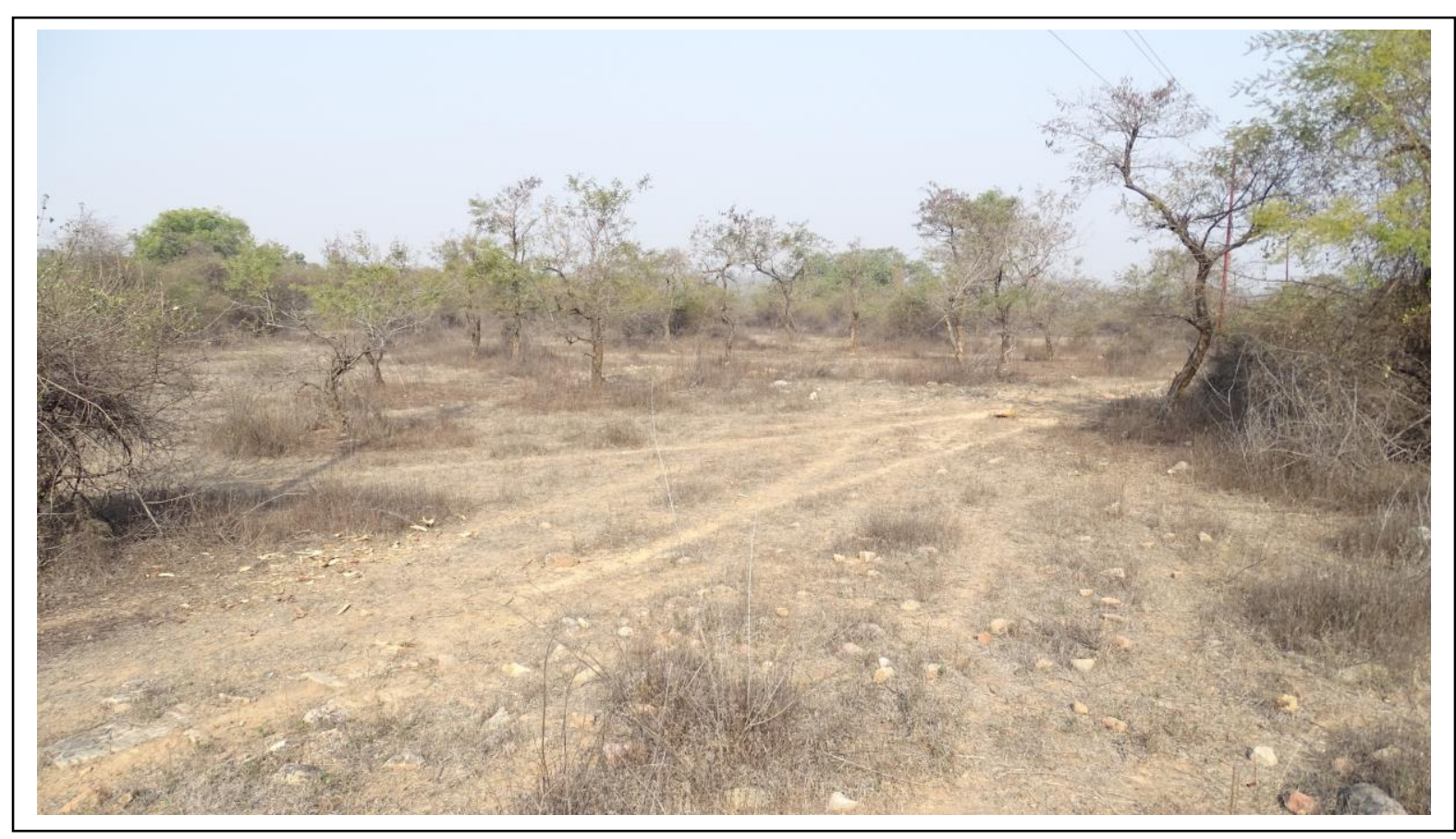

Figure 10 - The opening of forests in Madhihan. 


\section{References}

Arc GIS version $10.0 \quad(1999-2010) \quad$ ESRI Inc.(www.esri.com).

Areendram, G., Krishna R., Mazumdaar S. (2011).Geospatial modelling to assess elephant habitat suitability and corridors in Northern Chattisgarh, India. Tropical Ecology. 52(3); 275-283.

Bhat S.D., Rawat G.S.(1995). Habitat use by Chetal(Axis axis) in Dhaulkhand, Rajaji Natonal Park,India. Tropical Ecology, 36(2):177-189.

Champion, H.G., Seth SK. (1968). A revised classification of the Forest Types in India Manager publications. GOI, India, New Delhi.

Das, M.K., Awasthi, A.K., Pandey, R., Dwivedi, A., Koul, M. (2007). Mapping of forest types and land use/land cover of Singrauli coal field area using satellite remote sensing techniques. Journal of Tropical Forestry 23:141-150.

De Fries, R., Hansen, A., Newton, A.C., Hamsen, M.C. (2005). Increasing isolation of protected areas in tropical forests over the past 20 years. Ecological. Applications 15(1): 19-26.

ERDAS Imagine, 9.0 (2005). ERDAS field guide. Copyright Leica Geosystems. Geospatial Imaging, LLC. (1991-2005).Printed in USA.

Gooding, R.F., Rackham, D., Holland, J.P. Robertson, D. (1997). Detailed surveying and mapping of plant communities on featureless terrain. Grass and Forage Science, 52,439-444.

Goparaju L., Sinha D. (2015). Forest cover change analysis of dry tropical forests of Vindhyan highlands in Mirzapur district, Uttar Pradesh using satellite remote sensing and GIS. Ecological Questions 22/2015: $23-37$.

Harris, S., Cresswell, W.J., Forde, P.G., Trewhella, W.J., Woollard, T. Wray, S. (1990). Home-range analysis using radio-tracking data - a review of problems and techniques particularly as applied to the study of mammals. Mammal Review, 30, 97-123.

Javed, A., Khan, I. (2012). Landuse/Land cover change due to mining activities in Singrauli Industrial belt, Madhya Pradesh using remote sensing and GIS, Journal of Environmental Research and Development 6: 521-529.

Johnsingh, A.J.T., Joshua, J. (1994). Conserving Rajaji and Corbett national Parks: the Elephant as a flagship species. Orya 28:135-140.
Kamat, D.S. (1986). An integrated approach to remote sensing studies for wildlife habitat evaluation. In: D.S. Kamat and H.S.Panwar (Eds.) Proceedings of seminar cum workshop on wildlife habitat evaluation using remote sensing techniques, IIRS, Dehradun, pp165-182.

Khanna, V., Ravichandran, M.S., Kushwaha, S.P.S. (2001). Corridor analysis in Rajaji -Corbett Elephant reserve .A remote sensing and GIS approach. Journal of the Indian Society of Remote Sensing 29: 41-46.

Kumar, A., Marcot, B.G., Saxena, A. (2006). Tree species diversity and distribution patterns in the tropical forests of Garo Hills. Current Science 91(10): 13701381.

Kushwaha, S.P.S., Hazarika, R. (2004). Assessment of habitat loss in Kameng and Sonitpur elephant reserves. Current Science 87:1447-1453.

Kushwaha, S.P.S., Khan, A., Habib, B., Quadri, A., Singh, A. (2004). Evaluation of Sāmbhar and Muntjak habitats using geostatistical modelling. Current Science 86:10.1390 -1400.

Lang R. L., Shao,G., Pijanowski,B.C., Farnsworth,R.L., (2008). Optimizing unsupervised classifications of remotely sensed imagery with a data-aided labeling approach. Computers and. Geosciences 34, (12), 1877 1885.

Lillisend, T.M. Keifer, R. (2004). Remote sensing Image interpretation. John Wiley, New York.

Lu D. S., Weng Q. H., (2007). A survey of image classification methods and techniques for improving classification performance. International Journal of Remote Sensing 28, (5 ), 823 -870.

Mayers, N. (1991). Tropical forests: present status and future outlook. Climate change 19:3-32.

Mayers, N. (1992). The primary source: Tropical Forests and Our Future. Norton, New York.

Mishra, C., Johnsingh, A.J.T. (1996). On habitat selection by the Goral (Naemorhaedus goral) bedfordi (Bovidae Artiodactyla). Journal of Zoology 240:573-80.

Mondal, P., Southwoth, J. (2010). Protection versus commercial management spatial and temporal analysis of land cover changes in the tropical forests of central India. Forest Ecology and Management 259 (5): 1009-1017. 
Murphy P.G., Lugo A.E. (1986). Ecology of tropical dry forest. Annual Review of Ecology and Systematics. 17: 6788.

Nandy, S., Kushwaha, S.P.S., Mukhopadhyaya, S. (2007). Monitoring the Chilla -Motichur wildlife corridor using geospatial tools. Journal for Nature Conservation 15:237-244.

Panwar, H.S. (1986). Forest cover mapping for planning tiger corridor between Kanha and Bandavgarh- a proposed project. In: D.S. Kamat and H.S.Panwar (Eds.) Proceedings of seminar cum workshop on wildlife habitat evaluation using remote sensing techniques, IIRS, Dehradun. pp 209-212

Pimm SL., Russel G.J., Gittleman, Brooks T.M. (1995). The future of Biodiversity. Science: 269:347-350.

Prance, Ghillean T. (1982). Forest refuges: evidence from woody angiosperms. pp 137-157.In G.T.Prance (ed.) Biological Diversification in the Tropics. Columbia University Press, New York.

Pu R., (2009). Broadleaf species recognition with in situ hyperspectral data. International Journal of Remote Sensing 30, (11), $2759-2779$.
Raghubanshi, A.S., Tripathi, A.,(2009). Effect of disturbance, habitat fragmentation and alien invasive plant on floral diversity in dry tropical forest of Vindhyan highlands: a review. Tropical Ecology, 50:57-69.

Singh, A., (2007). Revegetation of coal mine spoils using Prosopsis juliflora in Singrauli coalfiled is a harmful practice from ecological viewpoint. Current. Science 93: 1204.

Singh, U., Narain, S. (2009). Ethnobotanical wealth of Mirzapur district, U.P., 135(2):185-197.

Yadav, P.K., Kapoor, M., Sarma, K. (2012). Land use land cover mapping change detection and conflict analysis of Nagzina-Navegaon corridor, Central India using Geospatial Technology. International Journal Of Remote Sensing and GIS 1(2): 90-98.

Submitted: 27.01.2017

Accepted: 27.04.2017 